MATEC Web of Conferences 53, 02004 (2016)

DOI: $10.1051 /$ matecconf/20165302004

(C) Owned by the authors, published by EDP Sciences, 2016

\title{
The Liberty Style - Italian Art Nouveau Architecture
}

\author{
Vasilii Goriunov ${ }^{1, a}$ \\ ${ }^{1}$ St. Petersburg State University of Architecture and Civil Engineering, 2-Krasnoarmejskaja, 4, Saint-Petersburg, \\ 190005, Russia
}

\begin{abstract}
This article refers the architecture of Italy of the end of the 19- the beginning of the 20 centuries. It shoes the origin of the term "Italian Liberty architecture", its main centers, its peculiarities and the buildings of its leading representatives. The assessment of importance of such studies provide the right understanding of the processes in European architecture of this time.
\end{abstract}

\section{Introduction}

All historians of architecture know very well that the term Art Nouveau has a lot of synonyms, accepted by researches of different countries. Most of these terms do not reflect the essence of the things and they are used conditionally. The exception is the term "Liberty Stile" although its origin also seems accidental like the origin of the majority of its synonyms. This term came from the name of the founder of British trading company which specialized on artworks from Japan and China.

This was the reason for the fact that many researchers are not quite accurately called this company one of the conductors of Japanese influence on European art. This was true as long as the company was engaged in the export of the works of art only. Soon, however the company began to cooperate with young British artists of applied art who created company s own style, which brought it European s fame. The basic principle of Liberty Style was the Celtic ornament-oriental influence was not very noticeable.

\section{The Italian Liberty Style architecture}

The greatest success of company Liberty was connected with Milan in the North of Italy where representative office of this firm was located. After the International Exhibition in Turin in 1902 “ The Liberty Style Architecture" became the symbol of what we would call the Italian Art Nouveau. At the same time it was forgotten very quickly that initially "Liberty" was the family name and soon " Liberty stile" became for Italian architects a style of Liberty. The fact is that in Italy "Liberty Style" acquired a new sense was not accidentally [1-3]. The main reason was in the emotional atmosphere which originated in Italy at the end of the 19-beginning of the 20 centures. Almost during the whole 19 century a fierce struggle for unification of Italy was going on. This process was resulted with unification of the country in 1871.At the same time within the centralized state some centrifugal

\footnotetext{
${ }^{\mathrm{a}}$ Corresponding author : vsgorunov@rambler.ru
} 
tendencies were still strong enough. Cultural differences between the various parts of the country and contradictions between the North and the South even now are very serious (2)

In this regard the Italian architecture is marked by the processes typical for other European countries. The "Thirst for style" seen in the architecture of the most European countries was realized in the attempts to create a new formal language of architecture for general use. This "thist" was minimal in Italy because from one side we find great historical tradition, and from another there was strong aspiration for creative freedom. Thus the unique situation emerged when the eclectics was the most suitable way for the development of architecture in that country. New forms of Art Nouveau were admitted first of all as the enrichment of decorative means and often were combined with traditional elements of architectural forms. Even the concept of "Liberty Stile" contained a certain contradiction. The point is that the term "Style" always means " regulation", " order", strictly speaking-something contrary to freedom. In Italian architecture aspiration to freedom dominated over aspiration to order. Thus the "thirst" for style which inspired the representatives of anti-eclectic movement of the end of the 19 century was very weak in the Italian applied art and architecture where prevailed individualism combined with personal tastes and preferences. This circumstancies together with very deep artistic roots of Italian culture resulted mostly eclectic character of " Liberty Style" which quickly approached to what Zeldmaier called " aesthetic Anarchism" [4, 5].

The Art Nouveau architects failed to create international style because their historical tastes , theoretic basis, even purposes were very diverse. Art Nouveau never was a single style but it was a collection of local styles which contrasted to each other being at the same time in the stage of interaction.(3). In one of our works we justify the position that of all stylistic trends in the Art Nouveau Architecture the closest to the ideal of the Great style was Finnish architecture (4). "Liberty Style" was the most remote variant [6-8].

The transition from classical eclecticism to the stage of Art Nouveau in Italy was relatively late and so decisive as in many other countries. The eclectic architecture in Italy never seemed decadent and was received favorably both by critics and by public. "Liberty style" in Italy included both traditional eclectic motives and those invented in the end of the 19 century. Thus eclectic architecture in Italy reached its last limit, using new elements [9]. This was possible because the eclectic and Art Nouveau architecture in Italy were more united than divided. The proximity to eclecticism and vague stylistic characteristics of "Liberty Style" in Italy led to the fact that Italian architecture of this period was out of sight of researchers of European architectural history. Meanwhile its uniqueness, originality, high aesthetic quality cause the respect and deep interest." Liberty Style" in Italy was widespread. We can find the examples of its structures in all regions of Italy. Nevertheless there were several centers where the "Liberty style architecture was concentrated. First of all is Turin, where The International Exhibition of 1902 was located [10]. Its main architect was Raimondo D Aroncothe builder of the pavilions (Figure 1).

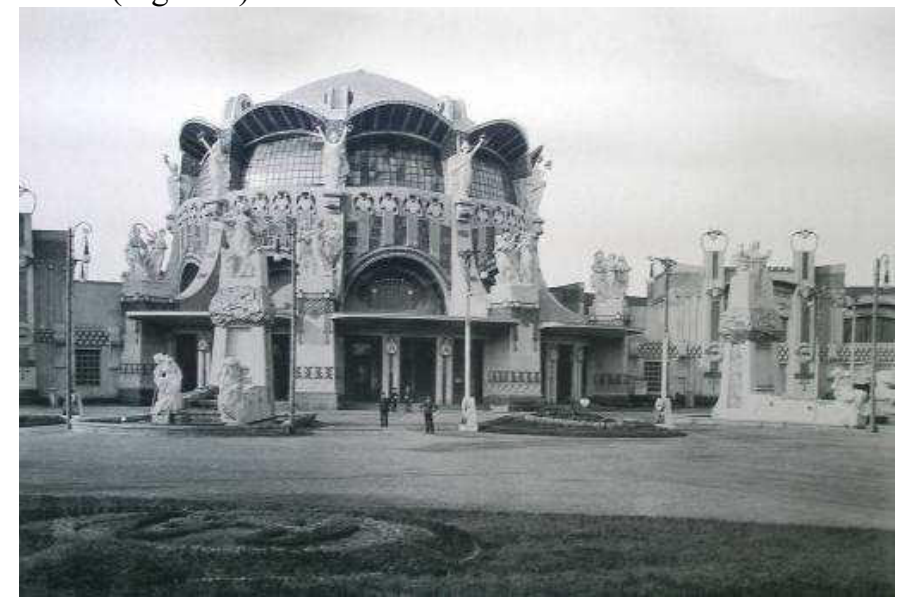

Figure 1. The main pavilion of the International Exhibition. 1902. D. Aronco 
Known as a restorer of Saint-Sophia Cathedral in Istambul, D Aronco created one of the most widespread variants of "Liberty Style" which sometimes is called "Floreal". Its soarces can be found in the style of the Viennese Art Nouveau school in the interpretation of Josef Olbricht and Otto Wagner [11-13]. However this Style has not become the object of direct imitation but remained a personal "handwriting" of its creators, which inspired sometimes other architects for experiments in the field of artistic décor, The results of these experiments characterize the "Liberty "architecture in Turin.

Another important center of "Liberty" was Milan. It was here that the Italian office of British company "Liberty" was located. It was here that the most architects of Italian Art Nouveau workedPirovano, Bossi Kompanini, Arta and certainly Giuseppe Somaruga famous beyond the borders of Italy. Milan represented the stylistic diversity of " Liberty " architecture [14-17].

"Palazzo Castiglione" by Sommaruga built in 1901 together with the main pavilions of the Turin Exhibition represent Italian architecture of Art Nouveau period in Italy and abroad. (Figure 2)

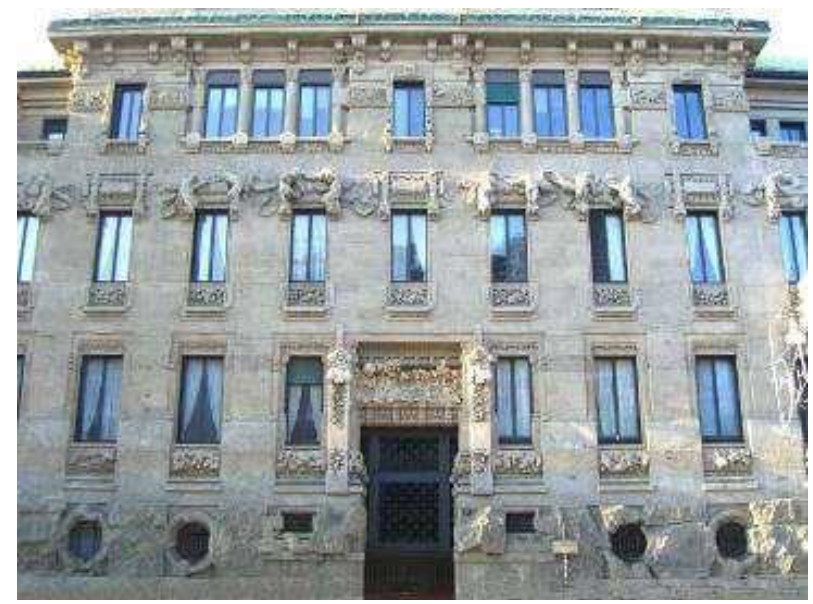

Figure 2. "Palazzo astiglione" by Sommaruga.

For understanding of "Liberty" architecture the great interest represent The Raman quarter named after its creator architect Gino Cappede (Figure 3)

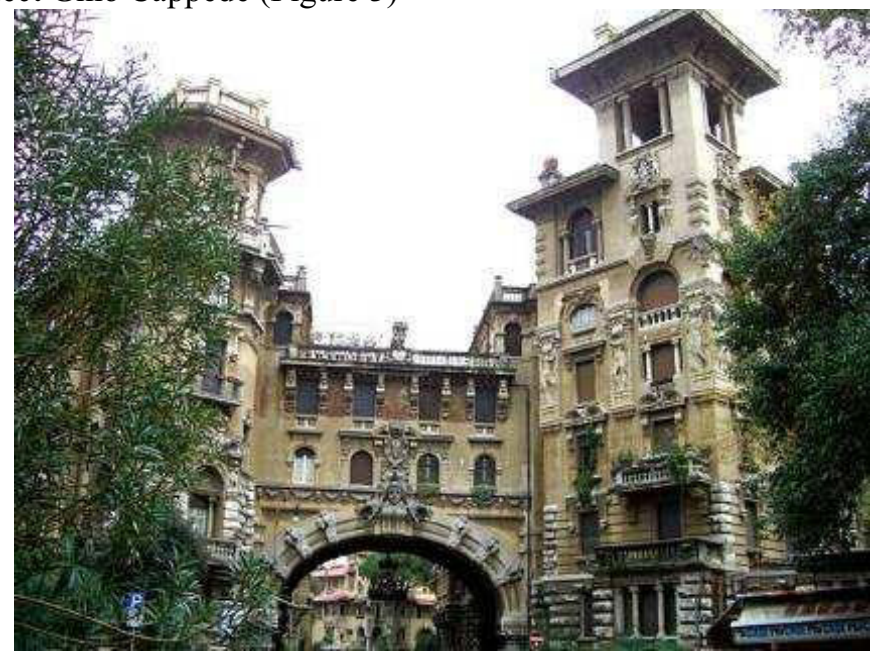

Figure 3. The Raman quarter Cappede, 1920 
The architecture of this quarter as well as all buildings of Cappede and his brother Adolfo is very eclectic basing on classical tradition. At the same time it is sufficiently original including some details typical for Art Nouveau. Italian Art historians call this buildings the example of "Liberty Style". Built in 1920-ies The Coppede quarter formed the bridge to the Art Deco architecture which inherited much from "histgoricism" of the past period $[18,19]$.

To understand better the development of Italian architecture one has to turn to the Sicilian architecture. This large island was always the territory of collision of different peoples and civilizations. So the architecture of Sicily was a mixture of various traditions, forming the " delightful caos of eclectics". It seems that the influence of the traditional architecture of Sicily made eclecticism acceptable and attractive in the eyes of Italian architects of Liberty period. Palermo became a centre of opposition to Futurism and avant-guard [20-24].

One of the most famous and influentional figures was Sicilian architect Ernesto Basile who worked in Palermo. Commissioned by the family Florio and constructed by Basile "Grand Hotel" in Palermo was considered an example of comfort and at the same time it became an example of creative freedom within the forms and motives of eclecticism. (Figure 4)

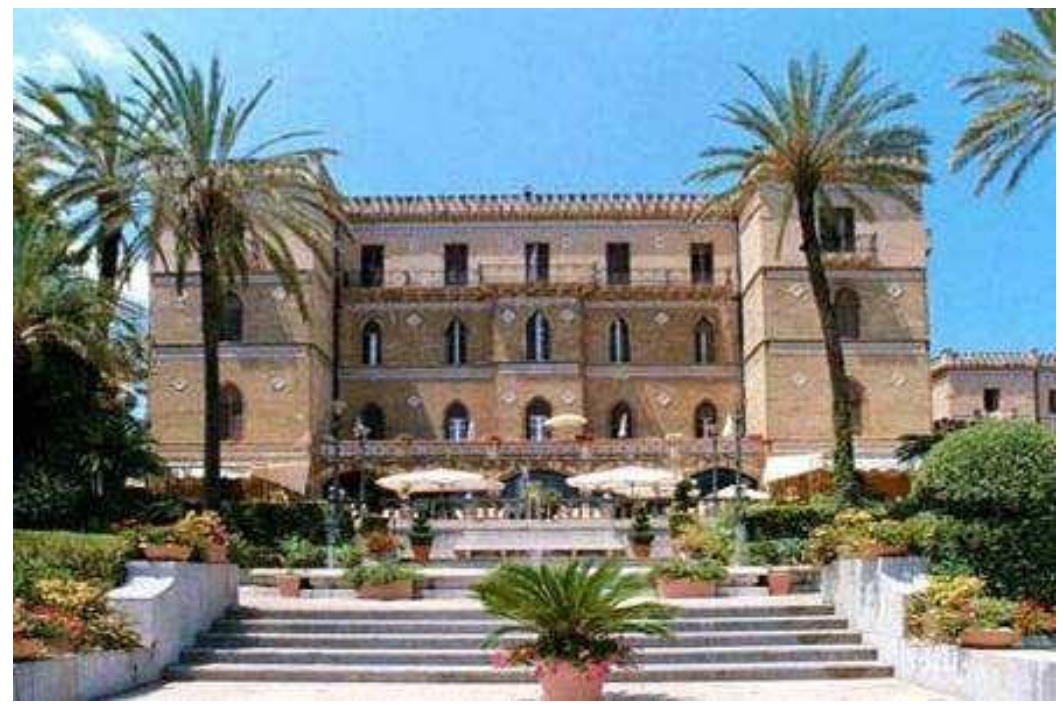

Figure 4. "Grand Hotel" in Palermo, 1898. Basile

Italian art critics considered Basile the founder of" Liberty style" of late 19 century. What was called in Italy " Liberty " architecture was closely connected with eclecticism and this allows us to suppose that the architecture of Art Nouveau period with all its anti-eclectic trends was the concluding stage of the great process that started at the time of Renaissance in Europe and was imbuied with " historicism". At the same time it may be called the result and the synthesis of 2 periods-of the Antiquity and of the Middle ages. The great change in the development of European architecture was caused the appearance of avant-guard with its tecnicism and anti-histiricism. Probably here we may find the answers on the main problem: what was the real place of Art Nouveau Architecture. Whether it continued the previous period or perhaps it is the beginning of new historic stage-the first stage of the contemporary architecture. Perhaps it presents independent part of European architecture differing from eclectic and from avant-guard [25-27].

In1912 in Milan a new group was founded-"New Tendecies"-an union of the Italian Art Nouveau artists. Among the members were two architects-Gino Coppede( the triumphant eclectic) and Antonio Sant-Elia(the young futurist). Two years later the" Manifesto of Futurist architecture" will be 
published, starting the new epoch.

\section{References}

1. V. Lintner, Italy. The history of the country (SPB, 2008)

2. C. Kin, Italy in the end of 19 century $(\mathrm{M}, 1978)$

3. V. Gorunov, M. Tubli, The architecture of the period of Art Nouveau (SPB, 1992)

4. V. Gorunov, The Nothern Art Nouveau and the Problems of Style (SPB, 2014)

5. L. Caramel, Longati, Antonio Sant-Elia (Como 1962)

6. N. Lipovac, A.M. Jandriček, Prostor, 19 (2), 443-455 (2011)

7. N. Lipovac, Prostor, 19 (1), 2-17 (2011)

8. V. Murgul, Procedia Engineering, 117, 808-818 (2015)

9. N. Lipovac, Prostor, 18 (2), 268-287 (2010)

10. N. Lipovac, Prostor, 5 (1), 1-33 (199

11. S. Kosanović, A. Fikfak, Energy and Buildings, (2015)

12. I. Čerpes, N. Pandol, A. Fikfak, European Countryside, 6 (3), 225-242 (2014)

13. C. Zappulla, C. Suau, A. Fikfak, Journal of Architecture and Urbanism, 38 (4), 247-264 (2014)

14. A. Fikfak, Journal of Architecture and Urbanism, 37 (4), 257-267 (2013)

15. S. Popović, N. Djurovic, V. Murgul, Procedia Engineering, 117, 832-840 (2015)

16. I. Yamshanov, V. Goryunov, V. Murgul, Procedia Engineering, 117, 675-684 (2015)

17. A. Olaj, P. Gabrijelčič, A. Fikfak, Geodetski Vestnik, 56 (1), 151-168 (2012)

18. I. Zayats, V. Murgul, Procedia Engineering, 117, 706-711 (2015)

19. V. Goryunov, I. Zayats, T. Konjkova, V. Murgul, Procedia Engineering, 117, 825-831 (2015)

20. V. Murgul, N. Vatin, I. Zayats, Procedia Engineering, 117, 824-829 (2015)

21. V. Murgul, V. Pukhkal, Procedia Engineering, 117, 891-899 (2015)

22. R. Alihodzic, V. Murgul, N. Vatin, Applied Mechanics and Materials, 680, 494-498 (2014)

23. I. Yamshanov, V. Goryunov, V, Murgul, Procedia Engineering, 117, 663-674 (2015)

24. Y. Nikitin, V. Goryunov, V. Murgul, N. Vatin, Applied Mechanics and Materials, 680, 504-509 (2014)

25. G. Radovic, V. Murgul, N.I. Vatin, Applied Mechanics and Materials, 584-586, 564-569 (2014)

26. A. Fikfak, G. Mrak, Glasnik SED, 50 (1-2), 48-56 (2010)

27. A. Fikfak, M.Z. Senegačnik, Glasnik SED, 48 (1-2), 2-67 (2008) 